\title{
Common Somatic Alterations Identified in Maffucci Syndrome by Molecular Karyotyping
}

\author{
Mustapha Amyere $^{\mathrm{a}}$ Anne Dompmartin ${ }^{f}$ Vinciane Wouters $^{\mathrm{a}}$ \\ Odile Enjolras $^{g} \quad$ Ilkka Kaitila ${ }^{\text {h }}$ Pierre-Louis Docquier ${ }^{b}$ Catherine Godfraind ${ }^{c}$ \\ John Butler Mulliken ${ }^{i}$ Laurence Myriam Boon ${ }^{a, d}$ Miikka Vikkula, ${ }^{a}$ \\ a Laboratory of Human Molecular Genetics, de Duve Institute, Université catholique de Louvain, ${ }^{b}$ Division of \\ Orthopedic Surgery, ' Laboratory of Pathology, and d Center for Vascular Anomalies, Division of Plastic Surgery, \\ Cliniques Universitaires St-Luc, and ' Walloon Excellence in Lifesciences and Biotechnology (WELBIO), Université \\ catholique de Louvain, Brussels, Belgium; ${ }^{\mathrm{f}}$ Department of Dermatology, Université de Caen Basse Normandie, CHU \\ Caen, Caen, and ${ }^{9}$ Consultation des Angiomes, Hôpital Lariboisière, Paris, France; ${ }^{\mathrm{h}}$ Department of Clinical Genetics, \\ Helsinki University Central Hospital, Helsinki, Finland; 'Department of Plastic and Oral Surgery, Children's Hospital \\ and Harvard Medical School, Boston, Mass., USA
}

\section{Key Words}

Cancer - Chondrosarcoma - Copy number variation - Defect . Enchondromatosis · Enchondroma - Gene - Microarray ·

Mutation $\cdot$ Spindle cell hemangiomas

\begin{abstract}
Maffucci syndrome (MS) is a rare congenital disorder characterized by multiple central cartilaginous tumors (enchondromas) in association with cutaneous spindle cell hemangiomas. These patients have a high incidence of malignant transformation. No familial case is known and the etiopathogenic cause remains unknown. In enchondromatosis (Ollier disease, OD), which is comprised of enchondromas only, 4 mutations in the PTHR1 gene have been identified in 4 patients; 3 were somatic and 1 was germline. No PTHR1 mutations have been detected in MS, whereas somatic IDH1 and, more rarely, IDH2 mutations have been observed in $77 \%$ of patients with MS and $81 \%$ of patients with OD. These genetic alterations are shared with other tumors, including glioma, leukemia and carcinoma. To search for underlying somatic
\end{abstract}

\section{KARGER}

E-Mail karger@karger.com

www.karger.com/msy genomic causes, we screened MS tissues using Affymetrix SNP-chips. We looked for CNVs, $\mathrm{LOH}$ and uniparental isodisomy (UPID) by performing pairwise analyses between allelic intensities in tumoral DNA versus the corresponding bloodextracted DNA. While common chromosomal anomalies were absent in constitutional DNA, several shared CNVs were identified in MS-associated tumors. The most frequently encountered somatic alterations were localized in 2 p22.3, $2 q 24.3$ and $14 q 11.2$, implicating these chromosomal rearrangements in the formation of enchondromas and spindle cell hemangiomas in MS. In one chondrosarcoma specimen, large amplifications and/or deletions were observed in chromosomes $3,6,9,10,12,13$, and 19. Some of these genetic changes have been reported in other chondrosarcomas suggesting an etiopathogenic role. No LOH/UPID was observed in any Maffucci tissue. Our findings identify frequent somatic chromosomal rearrangements on 2 p22.3, $2 q 24.3$ and $14 q 11.2$, which may unmask mutations leading to the lesions pathognomonic of MS.

(c) 2014 S. Karger AG, Basel

Odile Enjolras is deceased.
(0) 2014 S. Karger AG, Basel

1661-8769/14/0056-0259\$39.50/0
Prof. Miikka Vikkula

Laboratory of Human Molecular Genetics, de Duve Institute

Université catholique de Louvain, Avenue Hippocrate 74, PO Box B1.74.06 BE-1200 Brussels (Belgium)

E-Mail miikka.vikkula@uclouvain.be 
Table 1. Generalized enchondromatosis (Spranger classification)

\begin{tabular}{|c|c|c|c|c|c|}
\hline Name of condition & Major radiographic features & Etiology & $\begin{array}{l}\text { Chromosomal } \\
\text { location }\end{array}$ & Gene & References \\
\hline Ollier disease & $\begin{array}{l}\text { multiple enchondromas of flat and tubular bones, vertebrae } \\
\text { and calvaria evently distributed }\end{array}$ & $\mathrm{AD}$ or sporadic & $3 \mathrm{p} 22 \mathrm{p} 21.1$ & PTHR1 & $\begin{array}{l}\text { Hopyan et al., 2002; } \\
\text { Couvineau et al., } 2008\end{array}$ \\
\hline Maffucci syndrome & same as Ollier disease and multiple spindle cell hemangiomas & sporadic & - & $\begin{array}{l}\text { somatic IDH1 } \\
\text { and } I D H 2\end{array}$ & $\begin{array}{l}\text { Couvineau et al., 2008; } \\
\text { Amary et al., 2011; } \\
\text { Pansuriya et al., 2011 }\end{array}$ \\
\hline Metachondromatosis & $\begin{array}{l}\text { multiple enchondromas with prominent calcifications of } \\
\text { short tubular bones }\end{array}$ & $\mathrm{AD}$ & $12 \mathrm{q} 24.1$ & PTPN1 & $\begin{array}{l}\text { Sobreira et al., 2010; } \\
\text { Bowen et al., } 2011\end{array}$ \\
\hline Spondyloenchondrodysplasia & $\begin{array}{l}\text { irregularly distributed discrete enchondromas of long tubular } \\
\text { bones, generalized severe platyspondyly, mild or no involvement } \\
\text { of hands and feet }\end{array}$ & $\mathrm{AR}$ & $19 \mathrm{p} 13$ & TRAP & Briggs et al., 2011 \\
\hline $\begin{array}{l}\text { Enchondromatosis with irregular } \\
\text { vertebral lesions }\end{array}$ & $\begin{array}{l}\text { multiple enchondromas of long tubular and flat bones, } \\
\text { generalized irregular dysplasia of vertebral bodies, mild or } \\
\text { no involvement of hands or feet }\end{array}$ & sporadic & - & & Spranger et al., 1978 \\
\hline Generalized enchondromatosis & $\begin{array}{l}\text { generalized evenly distributed enchondromas, severe involvement } \\
\text { of hands and feet, mild platyspondyly, skull deformity }\end{array}$ & sporadic & $12 \mathrm{p} 11 \mathrm{p} 23$ & dupl PTHLH & Spranger et al., 1978 \\
\hline
\end{tabular}

$\mathrm{AD}=$ Autosomal dominant $\mathrm{AR}=$ autosomal recessive

Maffucci syndrome (MS) (OMIM 166000) is characterized by multiple enchondromas associated with superficial and deep vascular lesions, now called spindle cell hemangioma, a low-grade vascular tumor [Maffucci, 1881; Silva et al., 1986]. MS is rare with less than 200 cases reported; males and females are equally affected. The disorder appears in children aged between 4 and 5 years; however, $25 \%$ of cases are congenital. No familial inheritance has been shown [Boon and Vikkula, 2008].

MS lies in the spectrum of enchondromatoses, which were classified into 6 subtypes by Spranger, depending on the distribution of enchondromas, other signs and symptoms, and mode of inheritance: type I, Ollier disease; type II, Maffucci syndrome; type III, metachondromatosis; type IV, spondyloenchondrodysplasia; type V enchondromatosis with irregular vertebral lesions; and type VI, generalized enchondromatosis (table 1) [Spranger et al., 1978; Bhargava et al., 2005; Pansuriya et al., 2010; Briggs et al., 2011].

Enchondromas are hamartomatous proliferations of chondrocytes within long bones leading to an abnormal endochondral ossification of the diaphysis or the metaphysis. These tumors can appear anywhere, be unilateral or bilateral, but are always asymmetric. They are most often found on radiographic imaging performed for skeletal deformities, such as pathologic fracture, bony distortion, scoliosis, and short stature [Lewis and Ketcham, 1973; Kaplan et al., 1993; Albregts and Rapini, 1995]. On conventional radiographs, enchondromas are seen as multiple, oval-shaped osteolytic lesions with well-defined mar- gins in the metaphysis and/or the diaphysis of long tubular and flat bones.

Ollier disease (OD) (Spranger type I) is mainly sporadic, although rare familial cases have been reported [Hopyan et al., 2002; Rozeman et al., 2004; Casal et al., 2010]. The most frequent location for enchondromas is the small bones of the hands and feet (fig. 1A, C). MS (Spranger type II) is a similar enchondromatosis, but it is associated with slow-flow vascular lesions, which are blue, noncompressible, subcutaneous or cutaneous nodules, typically occurring on the fingers or feet (fig. 1B). Phleboliths may also be present. The lesions consist of dilated capillary-venous vessels that are more cellular in appearance than venous malformations and contain a variable number of spindle cells. These lesions were once thought to be low-grade angiosarcomas, but are now considered to be benign spindle cell hemangiomas (fig. 1D) [Haga et al., 1998; Boon and Vikkula, 2008]. Lymphatic malformations can also be seen in patients with MS. The hemangioendotheliomas are sometimes associated with lymphatic malformations [Suringa and Ackerman, 1970; Haga et al., 1998; Colonna et al., 2002; Auyeung et al., 2003]. In contrast to patients with venous malformations, MS patients have normal D-dimer levels [Dompmartin et al., 2009]. This is probably due to the more cellular composition of spindle cell hemangiomas and differing etiopathogenesis.

Patients with enchondromatosis, especially those with MS, have a significant risk (nearly 100\%) of developing skeletal and nonskeletal malignant lesions after 40 years 

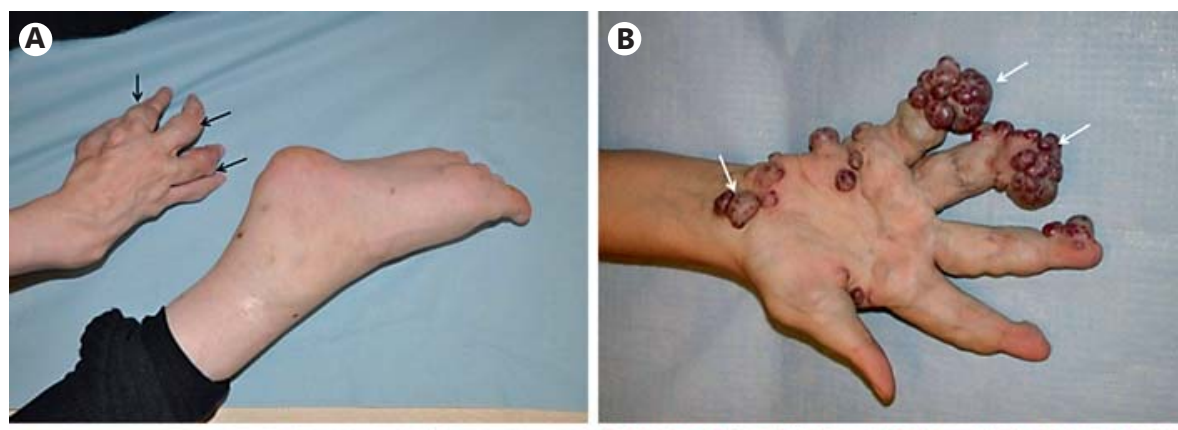

Fig. 1. Clinical features of OD and MS. A Classic deformities of the left hand and the left foot of a patient with OD showing multiple enchondromas (arrows). B Enchondromas associated with spindle cell hemangiomas (arrows) in the right hand of a patient with MS. C Hematoxylin-eosinstained section of enchondroma. D Spindle cell hemangioma demonstrating dilated vascular structures (asterisks). Inset Spindle cells.
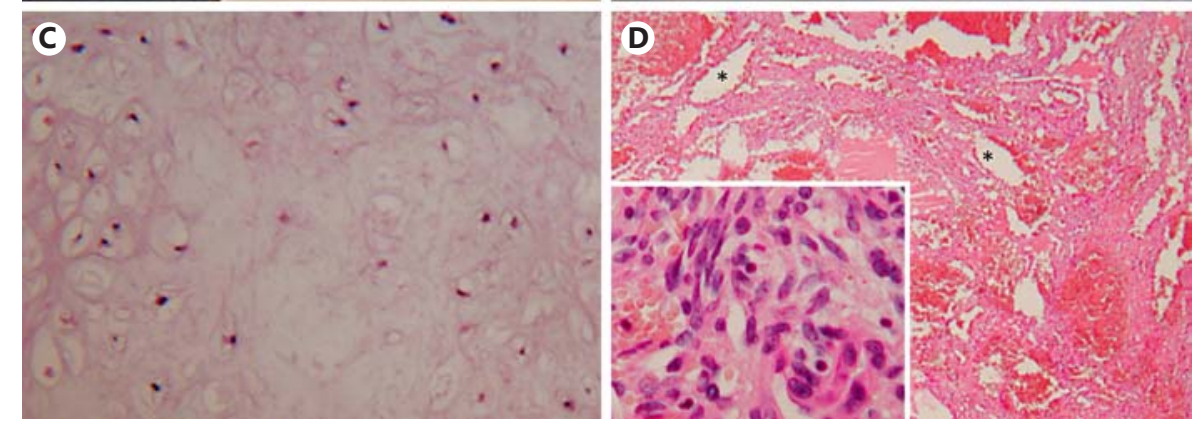

of age [Auyeung et al., 2003]. Sarcomatous degeneration of endochondromas may occur; it is difficult to differentiate a benign endochondroma from a low-grade malignant chondrosarcoma. In MS patients, most chondrosarcomas are of low histological grade (grade 1 or 2) and are successfully managed by surgical resection [Schwartz et al., 1987]. Other mesodermal neoplasms include fibrosarcoma, glioma, astrocytoma, ovarian tumors, hemangiosarcoma, and leukemia [Albregts and Rapini, 1995]. In $30 \%$ of cases, non-mesodermal tumors, such as adenocarcinoma, also occur. Therefore, careful and prolonged clinical follow-up and imaging studies are necessary.

Karyotyping is usually normal in patients with MS and OD. Somatic LOH on 13q14 and 9p21, as well as deletion in $1 \mathrm{p}$ and inversion in chromosome 9 , were found in rare patients with enchondromatosis [Ozisik et al., 1998; Bovée et al., 2000, 2001]. Overexpression of p53 has been noted in benign and metastatic cartilaginous tumors [Bovée et al., 1999, 2000, 2001]. Metachondromatosis (Spranger type III) is caused by germline mutations in PTPN11 with a likely loss of the second allele due to a somatic secondhit [Sobreira et al., 2010; Bowen et al., 2011]. Missense mutations have been reported in the parathyroid hormone receptor 1 (PTHR1) gene in 5 patients with enchondromatosis (Spranger type I), but no change in 23 patients with MS [Hopyan et al., 2002; Couvineau et al., 2008]. These findings suggest that, notwithstanding clinical overlap, MS and OD are not allelic disorders. Mutations in PTHR1 are infrequent even in OD; another study of 31 patients failed to identify any such mutation [Rozeman et al., 2004]. The complex phenotype of MS suggests that it is either a contiguous gene disorder caused by a deletion of multiple genes or that it is caused by a mutation in a gene with pleiotropic, growth-promoting effects. Whole genome screening could help identify loci and candidate genes involved in the development of enchondromas, vascular malformations and cancers. As SNP arrays offer high resolution and the possibility of distinguishing between 2 genotyped alleles, it is a powerful tool for the detection of allelic imbalances [Wang et al., 1998; Yamamoto et al., 2007; Amyere et al., 2013]. In this study, we identified several somatic CNVs in most of the tissue samples taken from patients with MS.

\section{Materials and Methods}

\section{Recruitment of Patients}

In collaboration with several clinicians, we collected blood and samples of resected tissues from patients with MS or OD. Informed consent was obtained from all patients in the study prior to participation, as approved by the ethical committee of the medical faculty at Université catholique de Louvain, Brussels, Belgium. The series comprised 9 blood and 9 frozen tumor samples from patients with MS as well as 1 blood and 2 frozen tissue samples from 2 patients affected by OD. Clinical information was collected by physicians who care for the patients (L.M.B., I.K., P.-L.D., O.E., and J.B.M.). 
Table 2. Clinical data of patients with MS or OD

\begin{tabular}{|c|c|c|c|c|c|c|c|c|c|c|c|c|}
\hline No. & Patient & Sex & Disease & \multicolumn{4}{|c|}{ Vascular anomalies in spindle cell hemangioma } & \multicolumn{4}{|c|}{ Enchondroma } & $\frac{\text { Cancer }}{\text { other anomaly }}$ \\
\hline 2 & MAF-190 & M & MS & + & + & + & + & & + & + & & chondrosarcoma \\
\hline 3 & MAF-110 & M & MS & & + & & & & + & & & \\
\hline 4 & MAF-150 & $\mathrm{F}$ & MS & + & + & + & & & + & + & & \\
\hline 5 & MAF-160 & M & MS & & & + & & & & + & & \\
\hline 8 & MAF-210 & $\mathrm{F}$ & OD & & & & & & + & + & & \\
\hline 9 & MAF-250 & $\mathrm{F}$ & MS & & + & + & & & + & + & & \\
\hline 10 & MAF-260 & M & MS & & & + & & & & + & & \\
\hline 11 & OLR-30 & M & OD & & & & & & & + & & \\
\hline
\end{tabular}

$\mathrm{UE}=$ Upper extremities; $\mathrm{LE}=$ lower extremities; $\mathrm{AML}=$ acute myeloid leukemia; $\mathrm{VWD}=$ von Willebrand disease.

\section{DNA Isolation}

Venous blood samples were drawn from participants and DNA was extracted from buffy coats using QIAamp DNA blood mini kit (Qiagen) or from whole blood using DNA purification kit (Gentra). DNA was extracted from pieces of frozen tissues using Puregene, DNA extraction kit (Gentra).

\section{SNP Array Analysis}

Eleven samples were investigated using SNP arrays (100K or SNP6.0), according to manufacturer's instructions (Affymetrix, Santa Clara, Calif., USA). Results were analyzed for copy number changes using Affymetrix genotyping console 4.1.4 (http://www. affymetrix.com) and CNAG 3.3.0.1 (http://www.genome.umin. jp). Genotype-calling algorithms MPAM Mapping or Birdseed v2 were used to generate the genotypes for 100K and SNP6.0 chips, respectively. When pairwise analysis (comparing tissue-extracted and blood-extracted DNA) from the same patient was employed, copy number status was inferred using algorithms based on the Hidden Markov Model [Nannya et al., 2005; Yamamoto et al., 2007]. Perfectly matched probes (for 100K and SNP6.0) and mismatched probes (for $100 \mathrm{~K}$ only) were used to calculate the ratios between the 2 alleles.

Databases

UCSC Genome Browser (http://genome.ucsc.edu) and Database of Genomic Variants (http://projects.tcag.ca/variation/).

\section{Results}

\section{Characteristics of the Patients}

Nine patients with MS and 2 patients with OD were included in our analysis (table 2). The 9 MS patients had both spindle cell hemangiomas and multiple enchondromas. The spindle cell hemangiomas were located in the feet (7/9), hands and fingers (6/9), head and neck $(2 / 9)$, or trunk (2/9). Enchondromas were mainly located on the hands, feet and long bones. Patient MAF-190 had a chondrosarcoma located in the shoulder and patient MAF-170 developed acute myeloid leukemia. Family history for MS and OD was negative for all $11 \mathrm{pa}-$ tients.

\section{Pairwise Copy Number Analysis}

In order to detect possible candidate loci for MS and OD, we applied the GeneChip Human Mapping 100K or SNP6.0 on 10 blood-extracted and 11 tissue-extracted DNAs. Copy number analysis individually comparing each DNA sample to a set of 48 references did not reveal copy number changes in blood DNAs; however, several chromosomal imbalances were identified in tissular DNAs. Patient MAF-110 had a mosaic $1 \mathrm{p}$ deletion, found using pairwise copy number analysis (fig. 2). Three genomic variations (deletions or amplifications) were seen repeatedly: 2p22.3, 2q24.3 and 14q11.2 (fig. 3; table 3). These chromosomal alterations do not share a common breakpoint, and they have variable sizes $(2.4-33.4 \mathrm{Mb})$ in 2p22.3, (1.1-6.5 Mb) in 2p24.3 and (1.5-25.6 Mb) in 14q11.2 (table 3). In one chondrosarcoma (MAF-190), we detected large chromosomal alterations by pairwise copy number analysis: deletions in 3q (26.1-29 Mb), 6q (13-27 Mb), 9p, 10q, 12p (13.33-12.1 Mb), and 13, and amplification of 12q12 (fig. 4) and deletion of 19p13.3q12 (data not shown). 
Fig. 2. Chromosomal anomaly in enchondroma of one MS patient (MAF-110) using Affymetrix 100K SNP-chip pairwise copy number analysis. Somatic deletion of complete chromosome $1 \mathrm{p}$ by decreased individual SNP-probe signals (red dots) and intensity ratios of alleles in tissue versus blood represented by a blue curve in a logarithmic scale. This deletion is highlighted by the increase in discrepancy calls between alleles in tissue versus blood (small pink bars) confirmed by loss of one allele (green line) in tissue and the increase of the LOH curve in blue.
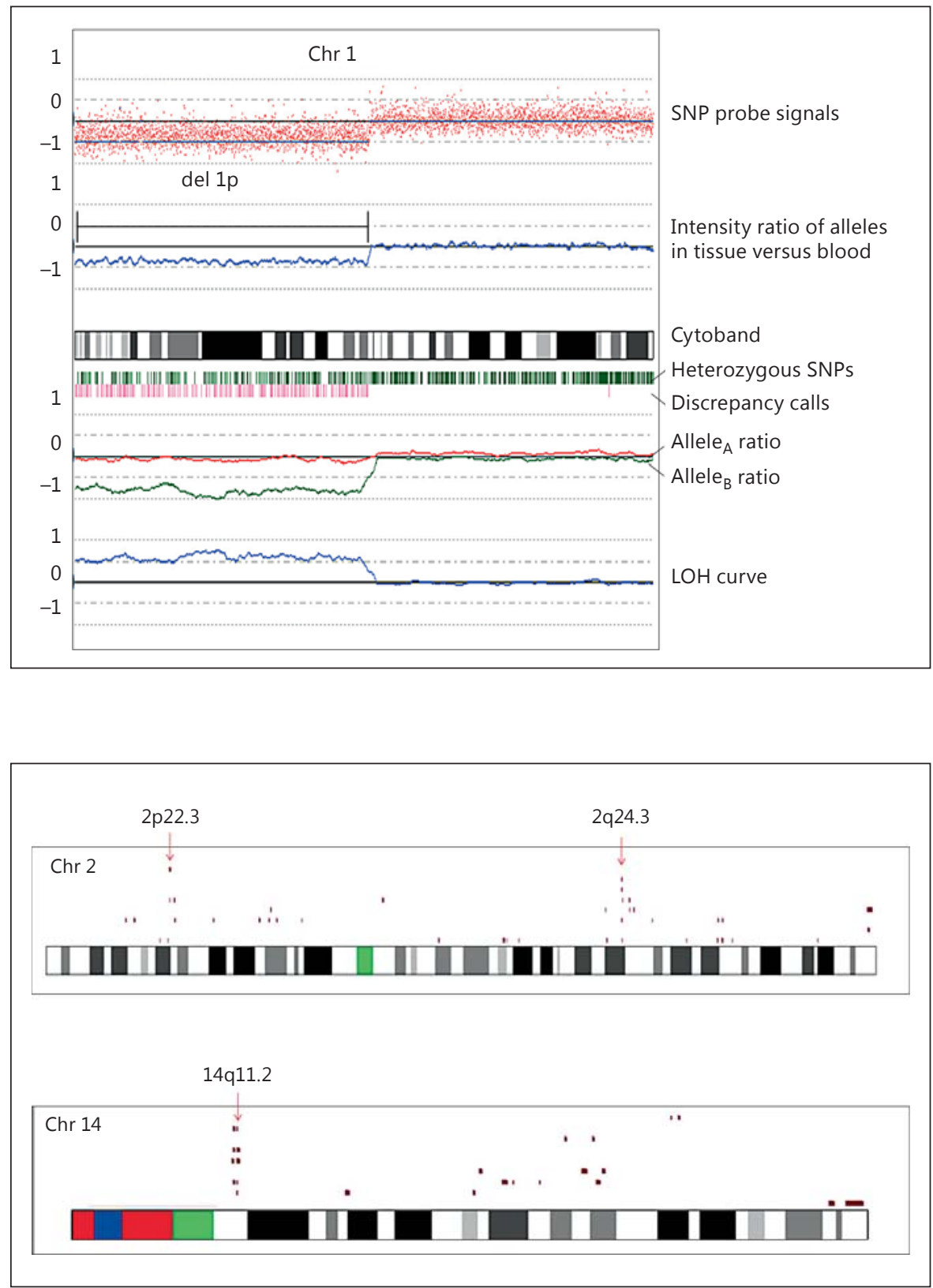

Fig. 3. Localization of common somatic amplifications/deletions in 10 Maffucci tissues genotyped using Affymetrix $100 \mathrm{~K}$ SNP-chip and detected by pairwise copy number analysis. Deletions or amplifications in each tissue are shown by red bars. Arrows show common amplifications/deletions in Maffucci tissues.

\section{Discussion}

We applied SNP arrays for a genome-wide screen of $\mathrm{LOH}$ and DNA copy number changes in a collection of tissue samples from patients with MS or OD. We compared paired blood and tissue DNAs. We identified large and small somatic areas of allelic imbalance in the Maffucci samples, but none in the enchondromas of OD. This suggests a point mutation in PTHR1 or another gene rather than a large deletion/amplification to explain the pathophysiology of OD [Couvineau et al., 2008]. The loci identified in Maffucci samples did not contain any of the genes that have been linked to enchondromatous lesions: PTHR1 (OD), PTPN11 (metachondromatosis), TRAP (spondyloenchondrodysplasia), PTHLH (generalized enchondromatosis) (table 1).

IDH mutations, IDH1 (R132C) and IDH2 (R172S) were found in 40 and in 50\% of tested Maffucci tissues, respectively (table 3 ). The presence of these mutations did not correlate with clinical features [Avakian et al., 2010; Shal- 
Table 3. Somatic genetic changes in Maffucci and Ollier patients

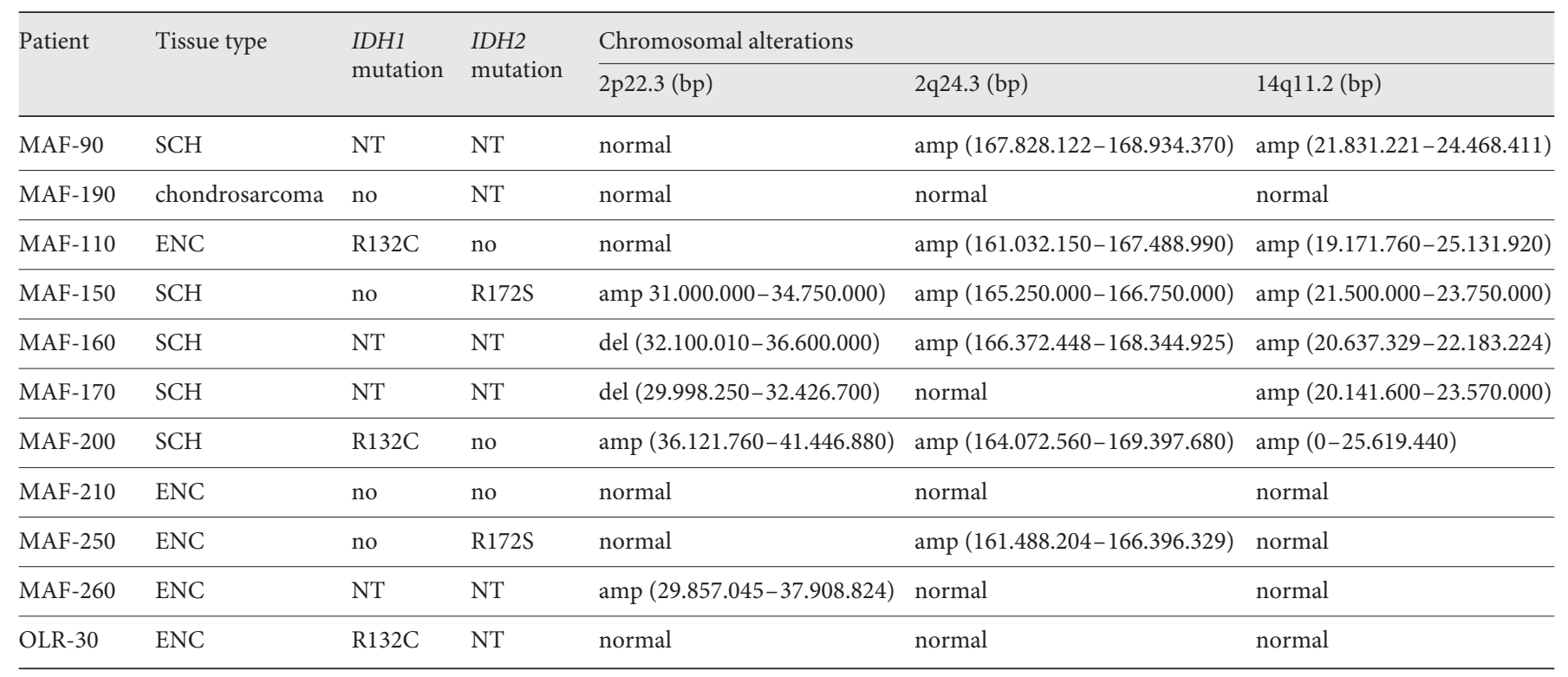

amp = Amplification; del = deletion; ENC = enchondroma; $\mathrm{NT}=$ not tested; $\mathrm{SCH}=$ spindle cell hemangioma.

aby et al., 2011]. Heterozygous hotspot mutations in IDH1/2 are frequently observed in several types of cartilaginous tumors, as well as in secondary glioblastomas, acute myeloid leukemia, and intrahepatic cholangiocarcinomas. IDH1/2 mutations cause epigenetic modifications, which can result in altered, pathophysiological expression of genes [Pansuriya et al., 2010; Cohen et al., 2013; Lee et al., 2013; Schaap et al., 2013]. However, novel potential driver mutations in the Capicua (CIC) have been identified as the key event to oligodendroglioma tumorogenesis in a background of IDH1/2 mutations [Yip et al., 2012].

Deletion/amplification of chromosomal DNA is thought to be one of the mechanisms that activate cancerrelated genes in tumors. Three regions, 2 p22.3, 2 q24.3 and $14 \mathrm{q} 11.2$, were frequently altered in Maffucci tissues. They have been reported as CNVs and in the Mitelman Database of Chromosomal Aberrations and Gene Fusions in Cancer. The 2 p22.3 region contains human microRNA (has-mir-558) predicted to target 182 genes, including PTPN11, that cause metachondromatosis (http:// www.targetscan.org/vert_50/). This region also contains the RASGRP3 gene, reported to promote activation of the ETS oncogene family member (ELK1) in a prostate cancer cell line [Schwartz et al., 1987]. 2p22.3 is reported to be associated with acute myeloblastic leukemia, adenocarcinoma and leiomyoma (Cancer Genome Anatomy Project (CGAP) http://cgap.nci.nih.gov/Chromosomes/
Mitel_Search?structural=on\&numerical=on\&breakpoin $\mathrm{t}=$ \&neopl=1101\&tissue $=$ \&type $=$ \&page $=1$ \#MARK).

The 2 q24.3 region is associated with acute lymphoblastic leukemia and follicular lymphoma. Chromosomal imbalances in this region are detected in highly malignant human colon cancer cell lines [Ranger and Szymczak, 2009]. The third locus, 14q11.2, is associated with lymphoma, meningioma and adenocarcinoma. The locus contains the defender against cell death (DAD1) gene that encodes a regulator of programmed cell death and the Tcell antigen receptor (TCRA) gene, strongly associated with CNVs in lymphocytes and neutrophils, and involved in T-lymphocyte response with MHC. TCR genes are assembled through $\mathrm{V}(\mathrm{D}) \mathrm{J}$ recombination, a site-specific recombination process directed by the lymphoid-specific recombinase and ubiquitously expressed DNA repair proteins [Yulug et al., 1995; Krangel, 2009; Dash et al., 2011]. We also observed this alteration in ependymomal tumors and Burkitt lymphoma. Thus, the presence of this somatic CNV may reflect clonal expansion of cells rather than being the cause of the disorder. The other recurrent somatic chromosomal alterations identified in our study could unmask driver mutations for enchondromas. This hypothesis could be addressed with a target deep sequencing of these regions.

One Maffucci patient had a mosaic, complete $1 \mathrm{p}$ deletion (fig. 2). Rare chromosome 1 alterations, 1 p11p21 in- 

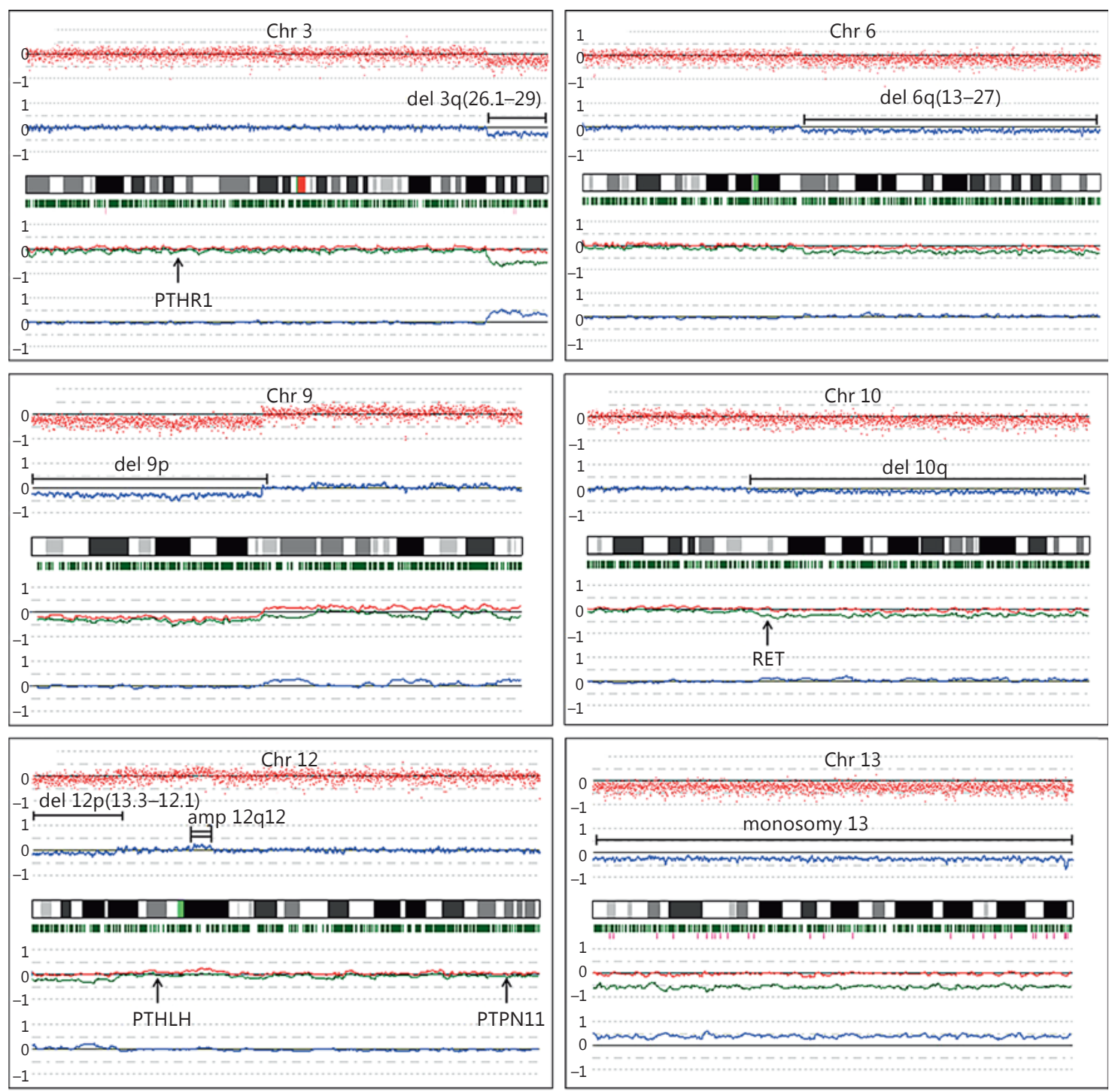

Fig. 4. Chromosomal anomalies in chondrosarcoma (MAF-190) using Affymetrix 100K SNP-chip pairwise copy number analysis. From the top, individual SNP probe signals (red dots); intensity ratio of alleles in tissue versus blood (blue curve in logarithmic scale); cytoband of each chromosome (black/white rectangles). Heterozygous SNPs are represented by green bars, and discrep- ancy calls between tissue and its corresponding blood by pink bars. Pairwise copy numbers between the same allele in tissue and in blood are represented by green and red lines, respectively, and the $\mathrm{LOH}$ curve is shown in blue. Deletions are delineated by horizontal black lines and amplifications by double horizontal lines. version (MS) and 1p11p31.2 deletion (OD), have been reported. $1 \mathrm{p} 36$ and $1 \mathrm{p} 13.2 \mathrm{p} 22.1$ deletions have been detected in chondrosarcomas [Matsumoto et al., 1986; Ozisik et al., 1998; Rozeman et al., 2004]. Thus, chromosome $1 \mathrm{p}$ may contain genetic material that is involved in the pathogenesis of the lesions in MS.

Mutation on arginine 132 of $I D H 1$ has been found in chondrosarcoma [Amary et al., 2011]. However, the majority of the alterations identified on the single chondro- sarcoma analyzed were large somatic chromosomal alterations: 3q26q29, 6q13q27, 9p, 10q, 12p and 13. Similar genetic anomalies have been reported in other chondrosarcomas, suggesting to be pathogenic [Rozeman et al., 2006] (table 1). The 10q deletion region contains the RET oncogene, which has been implicated in the pathogenesis of multiple endocrine neoplasia and papillary thyroid carcinomas, and $\mathrm{LOH}$ on 10q has been found in earlystage chondrosarcomas [Nannya et al., 2005]. Monosomy 
of chromosome 13 involves COL4A2, RAB20 and ING genes. COL4A2 is a structural component of basement membrane involved in (cartilaginous) differentiation [Romeo et al., 2007]. Missense mutations in this gene are associated with ocular defects and vascular stability, whereas RAB20 and ING genes are tumor suppressors [Amillet et al., 2006; Feng et al., 2006; Favor et al., 2007]. We also identified amplifications $12 \mathrm{q} 12$ and $19 \mathrm{p} 13.3 \mathrm{q} 12$ gain as reported in a chondrosarcoma of OD [Casorzo et al., 2003; Rozeman et al., 2006], and it is also frequently seen in the Mitelman cancer database.

No common abnormality was detected among the enchondromas and spindle cell hemangiomas. Tissue heterogeneity greatly impedes the detection of somatic alterations limited to a subset of cells. In this situation, the sensitivity of the currently available algorithms for $\mathrm{LOH}$ detection by SNP arrays is restricted [Amyere et al., 2013].

The array data was also analyzed for possible UPID, a mechanism well known to be involved in some cancers, such as neuroblastoma [George et al., 2007]. We have shown that it is the most frequent mechanism leading to complete localized glomulin dysfunction in glomuvenous malformations [Amyere et al., 2013]. Nevertheless, no somatic copy number neutral $\mathrm{LOH}$ region $>85 \mathrm{~kb}$ was detected in the Maffucci samples.
In conclusion, we identified frequent somatic alterations in $2 \mathrm{p} 22.3,2 \mathrm{q} 24.3$ and $14 \mathrm{q} 11.2$ that may play a role in causing enchondroma and spindle cell hemangioma. These regions probably contain genes involved in pathways that are dysregulated in MS. In addition, large chromosomal alterations were detected in a chondrosarcoma from a Maffucci patient; some of these changes are recurrent in other published studies. We could not detect any $\mathrm{LOH}$ or UPID region larger than $85 \mathrm{~kb}$, excluding this as a likely pathogenic mechanism. As we did not identify shared gains or losses of a single DNA segment in all of the individuals, the underlying genetic basis of MS may be a single gene defect with pleiotropic effects.

\section{Acknowledgements}

We are grateful to all the family members for their participation in this study. We acknowledge William Cole for referring a patient. These studies were partially supported by the Interuniversity Attraction Poles initiated by the Belgian Science Policy Office Interuniversity Attraction Poles (BELSPO-IAP) program through the project IAP P7/43-BeMGI, the F.R.S.-FNRS (Fonds de la Recherche Scientique), and the National Institutes of Health, Program Project P01 AR048564-01A1 (all to M.V.). M.A. was a 'Scientific Logistics Manager' of the F.R.S.-FNRS. V.W. was supported by a fellowship from F.R.I.A. (Fonds pour la formation à la recherche dans l'industrie et dans l'agriculture).

\section{References}

-Albregts AE, Rapini RP: Malignancy in Maffucci's syndrome. Dermatol Clin 13:73-78 (1995).

-Amary MF, Bacsi K, Maggiani F, Damato S, Halai $\mathrm{D}$, et al: $I D H 1$ and IDH2 mutations are frequent events in central chondrosarcoma and central and periosteal chondromas but not in other mesenchymal tumours. J Pathol 224: 334-343 (2011).

-Amillet JM, Ferbus D, Real FX, Antony C, Muleris $\mathrm{M}$, et al: Characterization of human Rab20 overexpressed in exocrine pancreatic carcinoma. Hum Pathol 37:256-263 (2006).

- Amyere M, Aerts V, Brouillard P, McIntyre BA, Duhoux FP, et al: Somatic uniparental isodisomy explains multifocality of glomuvenous malformations. Am J Hum Genet 92:188-196 (2013).

-Auyeung J, Mohanty K, Tayton K: Maffucci lymphangioma syndrome: an unusual variant of Ollier's disease, a case report and a review of the literature. J Pediatr Orthop B 12:147150 (2003).

Avakian H, Bosted P, Burkert VD, Elouadrhiri L, Adhikari KP, et al: Measurement of singleand double-spin asymmetries in deep inelastic pion electroproduction with a longitudi- nally polarized target. Phys Rev Lett 105: 262002 (2010)

Bhargava R, Leonard NJ, Chan AK, Spranger J: Autosomal dominant inheritance of spondyloenchondrodysplasia. Am J Med Genet A 135:282-288 (2005).

Boon LM, Vikkula M: Vascular malformations, in Wolff K (ed): Fitzpatrick's Dermatology in General Medecine, ed 7, pp 1651-1666 (McGraw-Hill Professional, New York 2008).

Bovée JV, Cleton-Jansen AM, Rosenberg C, Taminiau AH, Cornelisse CJ, Hogendoorn PC: Molecular genetic characterization of both components of a dedifferentiated chondrosarcoma, with implications for its histogenesis. J Pathol 189:454-462 (1999).

Bovée JV, van Roggen JF, Cleton-Jansen AM, Taminiau AH, van der Woude HJ, Hogendoorn PC: Malignant progression in multiple enchondromatosis (Ollier's disease): an autopsy-based molecular genetic study. Hum Pathol 31:1299-1303 (2000).

Bovée JV, Sciot R, Cin PD, Debiec-Rychter M, van Zelderen-Bhola SL, et al: Chromosome 9 alterations and trisomy 22 in central chondrosarcoma: a cytogenetic and DNA flow cyto- metric analysis of chondrosarcoma subtypes. Diagn Mol Pathol 10:228-235 (2001).

Bowen ME, Boyden ED, Holm IA, Campos-Xavier $\mathrm{B}$, Bonafé $\mathrm{L}$, et al: Loss-of-function mutations in PTPN11 cause metachondromatosis, but not Ollier disease or Maffucci syndrome. PLoS Genet 7:e1002050 (2011).

Briggs GD, Gordon SL, Dickson PW: Mutational analysis of catecholamine binding in tyrosine hydroxylase. Biochemistry 50:1545-1555 (2011).

- Casal D, Mavioso C, Mendes MM, Mouzinho MM: Hand involvement in Ollier disease and Maffucci syndrome: a case series. Acta Reumatol Port 35:375-378 (2010).

-Casorzo L, Chiecchio L, Pisacane A, Fumero S, Canavese $\mathrm{F}$, et al: Cytogenetic findings in a case of dedifferentiated chondrosarcoma. Cancer Genet Cytogenet 144:61-64 (2003).

-Cohen AL, Holmen SL, Colman H: IDH1 and IDH2 Mutations in Gliomas. Curr Neurol Neurosci Rep 13:345 (2013).

-Colonna G, Ascencio G, Meunier L, Guillot B: Lymphangioma in a patient with Maffuci syndrome of the lower legs [in French]. J Mal Vasc 27:174-176 (2002). 
Couvineau A, Wouters V, Bertrand G, Rouyer C, Lewis RJ, Ketcham AS: Maffucci's syndrome: Gérard B, et al: PTHR1 mutations associated with Ollier disease result in receptor loss of function. Hum Mol Genet 17:2766-2775 (2008).

-Dash P, McClaren JL, Oguin TH 3rd, Rothwell W, Todd B, et al: Paired analysis of TCR $\alpha$ and TCR $\beta$ chains at the single-cell level in mice. J Clin Invest 121:288-295 (2011).

Dompmartin A, Ballieux F, Thibon P, Lequerrec A, Hermans C, et al: Elevated D-dimer level in the differential diagnosis of venous malformations. Arch Dermatol 145: 1239-1244 (2009).

- Favor J, Gloeckner CJ, Janik D, Klempt M, Neuhäuser-Klaus A, et al: Type IV procollagen missense mutations associated with defects of the eye, vascular stability, the brain, kidney function and embryonic or postnatal viability in the mouse, Mus musculus: an extension of the Col4a1 allelic series and the identification of the first two Col4a2 mutant alleles. Genetics 175:725-736 (2007).

Feng X, Bonni S, Riabowol K: HSP70 induction by ING proteins sensitizes cells to tumor necrosis factor alpha receptor-mediated apoptosis. Mol Cell Biol 26:9244-9255 (2006).

-George RE, Attiyeh EF, Li S, Moreau LA, Neuberg $\mathrm{D}$, et al: Genome-wide analysis of neuroblastomas using high-density single nucleotide polymorphism arrays. PLoS One 2:e255 (2007).

-Haga N, Nakamura K, Taniguchi K, Nakamura S: Enchondromatosis with features of dysspondyloenchondromatosis and Maffucci syndrome. Clin Dysmorphol 7:65-68 (1998).

-Hopyan S, Gokgoz N, Poon R, Gensure RC, Yu C, et al: A mutant PTH/PTHrP type I receptor in enchondromatosis. Nat Genet 30:306-310 (2002).

-Kaplan RP, Wang JT, Amron DM, Kaplan L: Maffucci's syndrome: two case reports with a literature review. J Am Acad Dermatol 29:894899 (1993).

Krangel MS: Mechanics of T cell receptor gene rearrangement. Curr Opin Immunol 21:133139 (2009).

Lee D, Suh YL, Kang SY, Park TI, Jeong JY, Kim $\mathrm{SH}$ : IDH1 mutations in oligodendroglial tumors: comparative analysis of direct sequencing, pyrosequencing, immunohistochemistry, nested PCR and PNA-mediated clamping PCR. Brain Pathol 23:285-293 (2013). functional and neoplastic significance. Case report and review of the literature. J Bone Joint Surg Am 55:1465-1479 (1973).

Maffucci A: Di un caso di encondroma ed angioma multiple contribuzione alla genesi embrionale dei tumor. Mov Med Chir 3:339-412 (1881).

Matsumoto N, Fukushima T, Tomonaga M, Imamura M: Maffucci's syndrome with intracranial manifestation and chromosome abnormalities - a case report. No Shinkei Geka [in Japanese] 14Suppl 3:403-410 (1986).

- Nannya Y, Sanada M, Nakazaki K, Hosoya N, Wang L, et al: A robust algorithm for copy number detection using high-density oligonucleotide single nucleotide polymorphism genotyping arrays. Cancer Res 65:6071-6079 (2005).

Ozisik YY, Meloni AM, Spanier SS, Bush CH, Kingsley KL, Sandberg AA: Deletion 1p in a low-grade chondrosarcoma in a patient with Ollier disease. Cancer Genet Cytogenet 105: 128-133 (1998).

Pansuriya TC, Kroon HM, Bovée JV: Enchondromatosis: insights on the different subtypes. Int J Clin Exp Pathol 3:557-569 (2010).

Ranger A, Szymczak A: Do intracranial neoplasms differ in Ollier disease and Maffucci syndrome? An in-depth analysis of the literature. Neurosurgery 65:1106-1113 (2009).

Romeo S, Oosting J, Rozeman LB, Hameetman L, Taminiau AH, et al: The role of noncartilagespecific molecules in differentiation of cartilaginous tumors: lessons from chondroblastoma and chondromyxoid fibroma. Cancer 110:385-394 (2007).

Rozeman LB, Sangiorgi L, Briaire-de Bruijn IH, Mainil-Varlet P, Bertoni F, et al: Enchondromatosis (Ollier disease, Maffucci syndrome) is not caused by the PTHR1 mutation $\mathrm{pR} 150 \mathrm{C}$. Hum Mutat 24:466-473 (2004).

Rozeman LB, Szuhai K, Schrage YM, Rosenberg C, Tanke HJ, et al: Array-comparative genomic hybridization of central chondrosarcoma: identification of ribosomal protein S6 and cyclin-dependent kinase 4 as candidate target genes for genomic aberrations. Cancer 107:380-388 (2006).
Schaap FG, French PJ, Bovée JV: Mutations in the isocitrate dehydrogenase genes $I D H 1$ and IDH2 in tumors. Adv Anat Pathol 20:32-38 (2013).

Schwartz HS, Zimmerman NB, Simon MA, Wroble RR, Millar EA, Bonfiglio M: The malignant potential of enchondromatosis. J Bone Joint Surg Am 69:269-274 (1987)

Shalaby A, Presneau N, Ye H, Halai D, Berisha F, et al: The role of epidermal growth factor receptor in chordoma pathogenesis: a potential therapeutic target. J Pathol 223:336-346 (2011).

Silva EG, Phillips MJ, Langer B, Ordonez NG: Spindle and histiocytoid (epithelioid) hemangioendothelioma. Primary in lymph node. Am J Clin Pathol 85:731-735 (1986).

Sobreira NL, Cirulli ET, Avramopoulos D, Wohler E, Oswald GL, et al: Whole-genome sequencing of a single proband together with linkage analysis identifies a Mendelian disease gene. PLoS Genet 6:e1000991 (2010).

Spranger J, Kemperdieck H, Bakowski H, Opitz JM: Two peculiar types of enchondromatosis. Pediatr Radiol 7:215-219 (1978).

Suringa DW, Ackerman AB: Cutaneous lymphangiomas with dyschondroplasia (Maffucci's syndrome). A unique variant of an unusual syndrome. Arch Dermatol 101:472-474 (1970).

Wang DG, Fan JB, Siao CJ, Berno A, Young P, et al: Large-scale identification, mapping, and genotyping of single-nucleotide polymorphisms in the human genome. Science 280: 1077-1082 (1998).

-Yamamoto G, Nannya Y, Kato M, Sanada M, Levine RL, et al: Highly sensitive method for genomewide detection of allelic composition in nonpaired, primary tumor specimens by use of affymetrix single-nucleotide-polymorphism genotyping microarrays. Am J Hum Genet 81:114-126 (2007)

Yip S, Butterfield YS, Morozova O, Chittaranjan $\mathrm{S}$, Blough MD, et al: Concurrent CIC mutations, IDH mutations, and $1 \mathrm{p} / 19 \mathrm{q}$ loss distinguish oligodendrogliomas from other cancers. J Pathol 226:7-16 (2012).

Yulug IG, See CG, Fisher EM, Ylug IG: The DAD1 protein, whose defect causes apoptotic cell death, maps to human chromosome 14 . Genomics 26:433-435 (1995). 